\title{
PROBLEM RELATED PAPER TENSION AND ITS SOLUTION \\ IN NEWSPAPER PRODUCTION USING WEB OFFSET PRINTING MACHINE
}

\section{MASALAH KETEGANGAN KERTAS DAN SOLUSINYA DALAM PEMBUATAN KORAN MENGGUNAKAN MESIN CETAK WEB OFFSET}

\author{
Mawan Nugraha ${ }^{a^{*}}$, A Sarmada $^{\mathrm{a}}$, Ari Dwi Yulianto ${ }^{\mathrm{a}}$ \\ a Teknik Grafika, Politeknik Negeri Media Kreatif, Indonesia \\ "Email: mawan@polimedia.ac.id
}

\begin{abstract}
In-depth observations have been made on the web printing process for newspaper production. Observations were made to identify problems related to the tension of the roll paper used in the production of newspapers. The problem of roll-paper tension is observed from the main material, the upstream process (Reelstand Unit), the printing process and its supporting units such as the wetting unit, inking unit and in the folder unit which is a contineous process. From observing the problems in the printing process, the causes and solutions to the problems were identified which were then used as an operating standard reference for the newspaper production using a web offset printing machine.
\end{abstract}

Keywords—web offset printing machine, newspaper, paper tension

\begin{abstract}
Abstrak - Telah dilakukan pengamatan mendalam terhadap proses cetak web untuk produksi Koran. Pengamatan dilakukan untuk mengidentifikasi masalah yang terkait dengan tegangan kertas gulungan yang digunakan pada produksi koran atau surat kabar. Masalah ketegangan kertas teramati dari bahan pokok, proses hulu (Unit Reelstand), proses cetak beserta unit pendukungnya seperti unit pembasahan, penintaan dan pada bagian pengeluaran mesin cetak yang merupakan satu kesatuan proses. Dari pengamatan masalah proses cetak selanjutnya diidentifikasi penyebab dan pemecahan masalahnya yang selanjutnya dijadikan rujukan standar proses pencetakan Koran menggunakan mesin cetak offset gulungan.
\end{abstract}

Kata Kunci-mesin cetak ofset gulungan, suratkabar, ketegangan kertas.

\section{PENDAHULUAN}

Kemajuan teknologi industri cetak telah memberi pengaruh besar terhadap

perkembangan media informasi. Sejak 
ditemukannya sistem pencetakan pertama oleh seorang penemu berkebangsaan Jerman bernama Johannes Gutenberg pada tahun 1440. Keberagaman jenis media informasi yang berupa barang cetakanmenjadi salah satu contoh dari kemajuan industri cetak, misalnya surat kabaratau yang lebih sering disebut koran atau surat kabar (news paper) yang mampu mendominasi sumber berita manusia.(Wang, 2020)

Meskipun diakui saat ini pasar koran diakui mengalami penurunan karena bersaing dengan media digital, namun pada praktiknya pasar koran masih eksis untuk melayani kebutuhan informasi kalangan tertentu yang lebih nyaman menyimak berita secara non digital karena pengaruh budaya dan kebiasaan. (Ellger, Hilbig, Riaz, \& Tillmann, 2021)

Produksi koran selalu dilakukan secara masal, bukan on demand, sehingga lebih ekonomis diproduksi dengan mesin cetak cetak ofset konvensional. Proses cetak ini menggunakan prinsip pengalihan tinta tidak langsung yaitu lapisan tinta pada acuan/ pelat akan dialihkan ke bahan cetak dengan melalui perantaraan media kain karet. Kejadian pengalihan tinta yang tidak langsung inilah yang menjadi dasar peralatan ini yang disebut ofset. Istilah "ofset" (dari kata set-off $=$ beralih), sesuai dengan katanya, menjelaskan bahwa gambar dengan lapisan tintanya semula di atas permukaan pelat kemudian "dialihkan" dahulu ke permukaan kain karet (blanket) kemudian dialihkan lagi ke kertas dengan bantuan penekanan dari silinder tekan. Istilah "offset" selanjutnya dalam bahasa Indonesia ditulis “ofset.(Svendsen \& Rognes, 2000; Trifonova, 2020)

Cetak ofset pun terbagi menjadi dua jenis, yaitu cetak ofset lembaran dan cetak ofset gulungan atau web fed. Pada proses produksinya surat kabar/koran diproduksi menggunakan mesin cetak web ofset yang berbahan baku material kertas gulungan. Mesin ini dapat mencetak dengan oplah yang banyak dan hanya membutuhkan waktu produksi yang cukup singkat, akan tetapi cukup memakan waktu pada saat persiapan cetaknya. (https://www.prakashoffset.com) Sama halnya dengan mesin cetak ofset lembaran, mesin cetak web gulungan juga memiliki beberapa unit yang salah satunya adalah unit reel stand. Pada unit kertas gulungan yang merupakan bahan baku utama diletakkan dan kemudian kertas dialurkan ke rol-rol penghantar, unit cetak, unit pembasahan, dan terakhir ke unit folder sebagai unit pengeluaran. Banyak hal yang harus diperhatikan agar proses pencetakan berjalan lancar, terutama pada unit reel stand mulai dari kondisi mesin, keterampilan operator cetak, sampai kondisi fisik dan 
kelayakan bahan baku cetak karena unit ini merupakan awal proses pencetakan.

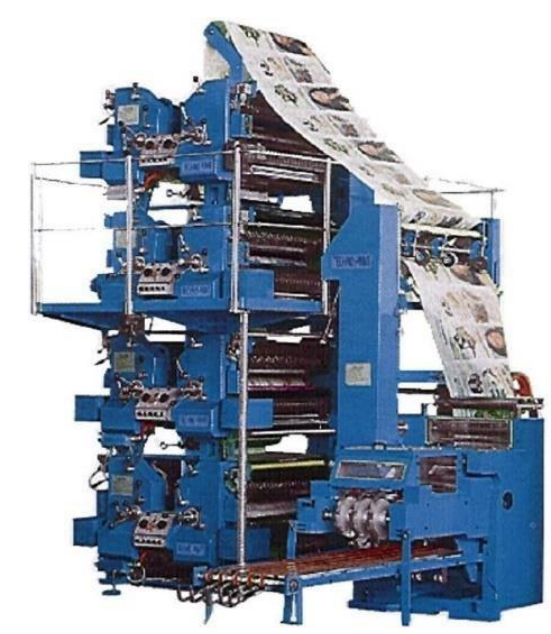

Gambar 1. Mesin web ofset

Untuk memproduksi koran, mesin cetak ofset ada yang dirancang secara khusus yang dikenal sebagai Newspaper web ofset yaitu mesin cetas ofset gulungan yang khusus mencetak bahan baku kertasnya dengan serat kayu seperti koran yang mudah menyerap tinta dan pengeringannya menggunakan penguapan atau oksidasi.(Manurova \& Horvath, 2020) Jadi ini tidak perlu ada tambahan rangkaian pada mesin ini. (Sudiyamto, 2010).

Dengan menggunakan mesin cetak web ofset maka produksi koran akan cepat dan murah terutama pada produksi masal harian. Disamping banyak kelebihannya, beberapa masalah juga sering muncul terkait dengan sistem cetak gulungan ini, sebagai berikut; ukuran potong tetap sehingga lay out cetakan harus standart; Persiapan cetak coba tidak bisa menggunakan kertas bekas; Karena speed tinggi, mengontrol register cetakan lebih sulit; Dot gain lebih besar; Rol-rol tinta sedikit sehingga kestabilan tinta dipermukaan plate kurang baik; Tinta yang digunakan cenderung mudah menyebar; Sulit mendapatkan ketepatan register warna ke warna. Beberapa kelemahan tersebut diperparah oleh pengaturan ketegangan kertas gulungan yang kurang baik.

Masalah ketegangan kertas kerap terjadi pada proses cetak web. Mulai dari persiapan, pencetakan, bahkan sampai paska cetakpun sering terjadi masalah ketegangan kertas di pencetakan web gulungan ini. Meskipun ketegangan krtas ini terkesan sepele, namun karena proses cetak web memiliki proses yang kontinyu terkait dengan suplai bahan kertas, maka begitu ada masalah, tingkat inefisiensi produksinya menjadi tinggi yang dapat menyebabkan kerugian perusahaan dengan cepat. Oleh karena itu, ketegangan kertas ini harus benarbenar dijaga agar produksi tidak terhambat. Kami melakukan pengamatan di PT T Jakarta untuk melihat bagaimana cara proses kerja mesin cetak web gulungan dan mengamati masalah yang disebabkan oleh ketegangan kertas pada proses cetak web gulungan berlangsung serta penyebab apa saja yang bisa mempengaruhi ketegangan kertas.

\section{METODE PENELITIAN}

Pada penelilitian ini kami mengamati secara langsung di lapangan prosedur teknis 
yang dilakukan untuk dapat mengantisipasi dan mengatasi masalah yang terjadi pada proses pencetakan yang disebabkan oleh pengaturan ketegangan gulungan kertas yang terpasang pada mesin.(Kulachenko, Gradin, \& Uesaka, 2005) Prosedur berikut menjadi perhatian kami secara seksama;

\section{Proses pemasangan kertas gulungan}

1. Menekan tombol Stop dan posisikan selector pada posisi SAFE, langkah ini bertujuan meminimalisir kemungkinan kecelakaan yang akan terjadi pada operator.

2. Memosisikan kertas gulungan berada tepat di bawah katrol pengangkat kertas, kemudian membuka kemasan kertas gulungan lalu sobek sebagian kertas gulungan yang masih menempel karena lem pemasangan kemasan.

3. Memasang as rol kertas, memosisikan as dengan benar lalu mengisi tekanan angin pada as rol kertas agar as rol dengan kertas gulungan terkunci.

4. Mengangkat kertas gulungan menggunakan katrol pengangkat dan menempatkan kertas gulungan pada unit Reelstand dengan benar, memastikan penepatan as rol berada pada posisi terkunci dengan unit reelstand dengan cara menggeser tuas penepat Reelstand.

5. Membuka tekanan cetak pada silinder tekan agar kertas dapat dengan mudah melalui setiap unit cetak.

6. Meregangkan hand wheel sepatu rem pada Reelstand

7. Menyobek ujung kertas gulungan sehingga membentuk segitiga siku-siku yang ujungnya dekat dengan operator side. Dengan bentuk seperti ini kertas dapat ditarik dengan rata melalui lintasan yang di gunakan

8. Kertas gulungan dapat dengan mudah ditarik melalui unit cetak, rol-rol pengantar sampai keunit folder, pada saat yang sama dibantu dengan memuter rol kertas untuk melepas kertas. Untuk lintasan yang agak rumit penarikan kertas gulungan dapat ditolong dengan pita kertas selebar $5 \mathrm{~cm}$. Mulaidari folder, pita kertas ini ditarik melalui lintasan yang di inginkan, kemudian pita kertas ditarik sambil rol kertas di puter dengan tangan untuk melepas kertas. Setelah ujung kertas melewati unit pertama, beri tekanan pada silinder tekan dan mesin dijalankan (inching) sambil menarik pita kertas padafolder.

9. Selanjutnya ujung kertas dimasukkan ke folder dengan bersamaan dengan lintasan yang lain.

10. Lalu pasang Web Break Detector, alat ini berfungsi untuk mendeteksi apabila kertas gulungan hampir habis agar segera mengganti dengan kertas gulungan yang 
baru.

\section{Mengatur tekanan kertas gulungan}

1. Pada saat mesin baru berjakan pegas dancing roller diatur untuk memberikan tegangan $16 \mathrm{~kg}$ sampai $34 \mathrm{~kg}$ pada dancing roller, dalamposisi tegak lurus.

2. Jika kertas gulungan lebih dari satu, pengaturan tegangan tertinggi pada unit yang terdekat ke folder dan terendah pada yang terjauh, langkah ini bertujuan agar tegangan kertas dapat konsisten sampai ke folder.

3. Setelah mesin berjalan cukup lama, rol kertas akan mengecil dan operator harus memperhatikan posisi dancing roller. Kemungkinan diperlukan pengendalian dancing roller untuk mempertahankan konsistensi tegangan kertas.

4. Jika tarikan terhadap web berkurang, dancing roller dan rangkaian penghubungnya akan bergerak kearah yang menyebabkan pengereman bertambah, sehingga tegangan akan kembali normal.

\section{Penyambungan Kertas Gulungan}

Pada dasarnya proses penyambungan kertas gulungan tidak jauh berbeda dengan proses pemasangan awal kertas gulungan, hanya saja ada beberapa tahapan yang tidak perlu dilakukan saat proses penyambungan kertas ini :

1. Menekan tombol Stop dan posisikan selector pada posisi SAFE, langkah ini bertujuan menimalisir kemungkinan kecelakaan yang akan terjadi padaoperator

2. Membuka tekanan cetak pada silinder tekan.

3. Membuka penepat as rol dengan Reelstand lalu turunkan sisa kertas gulungan dengan katrol pengangkat kertas.

4. Membuka as rol gulungan dengan mengosongkan tekanan angin pada as rol, gunakan pelindung saat memegang as rol yang baru di turunkan atau tunggu beberapa menit karena as rol menjadi panas akibat gaya gesekan saat proses pencetakan berlangsung.

5. Memposisikan kertas gulungan berada tepat dibawah katrol pengangkat kertas, buka kemasan kertas gulungan lalu sobek bagian kertas gulungan yang masih nempel karena lem pemasangan kemasan.

6. Memasang as rol kertas, posisikan as dengan benar lalu isi tekanan anginpada asrol kertas agar as rol dengan kertas gulungan terkunci.

7. Mengangkat kertas gulungan menggunakan katrol pengangkat dan tempatkan kertas gulungan pada unit Reelstand dengan benar, pastikan penepat as rol berada pada posisi terkunci dengan unit Reelstand dengan cara menggeser tuas penepat Reelstand. 
8. Memosisikan buntut kertas lama di ujung kertas gulungan baru.

9. Merekatkan kedua ujung kertas dengan perekat atau Double Tape, kemudian buang kertas yang berlebih, perlu di perhatikan, penggunaan perekat tidak boleh berlebihan karena pada saat melewati unit pencetakan dapat merusak blanket.

10. memberi tekanan silinder tekan, kemudian jalankan mesin dengan kecepatan rendah sampai sambungan ini melewati unit cetak dan unit folder

11. Menyesuaikan teganan kertas agar kertas tidak putus

\section{HASIL DAN PEMBAHASAN}

Hasil pengamatan lapangan kami tuangkan dalam bagian ini untuk menjelaskan keterkaitan masalah yang timbul pada tegangan kertas pada mesin cetak web dengan proses cetak, jumlah sampah cetak, efisiensi produksi dan potensi penyebab masalah, sebagai berikut.

\section{Pengaruh ketegangan kertas pada proses cetak web}

Banyak permasalahan-permasalahan yang dapat menghambat proses pencetakan dengan menggunakan mesin cetak web, salah satunya tegangan pada cetak web. Hal tersebut terjadi karena adanya beberapa faktor, diantaranya segi mekanik dari mesin itu sendiri, bahan baku yang digunakan,dan juga faktor manusia atau operator yang menjalankan mesin tersebut. Akan tetapi permasalahan-permasalahan yang ditimbulkan oleh faktor mesin dapat diminimalisir dengan melakukan perawatan secara rutin (preventif maintenance) dan disertai pengecekan terhadap setiap bagian mesin untuk mengetahui kelayakan kondisi mesin agar tidak terjadi permasalahan pada saat proses cetak berlangsung. Penggunaan bahan baku yang telah memenuhi standar yang sudah ditetapkan oleh suatu industri percetakan juga dapat menunjang kelancaran proses pemasukan kertas agar bisa berjalan dengan baik dan dapat menjaga mutu hasil cetakan

\section{Pengaruh ketegangan kertas terhadap paper/sampah kertas cetakan}

Masalah ketegangan kertas yang tidak maksimal terjadi pada proses cetak gulungan dan sangat mempengaruhi hasil akhir produksi, yaitu terlalu banyak bahan baku kertas yang terbuang/menjadi sampah kertas cetakan. Dalam hal ketegangan kertas yang tidak terjaga berdampak pada jumlah konsumsi bahan baku yang terlalu berlebihan melewati jumlah bahan baku kertas yang sudah direncanakan, yang mengakibatkan:

1. Kurangnya bahan baku yang dipakai dan perusahaan harus menambahbahan baku yang sudah ditetapkan. 
2. Banyaknya jumlah sampah kertas cetakan /waste paper yang melebihi target pada bagian perencanaan.

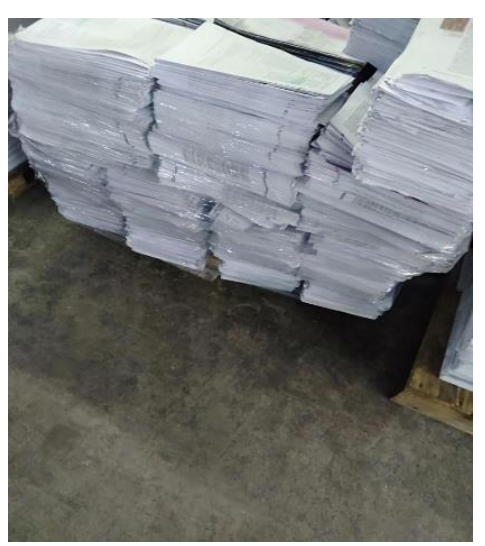

Gambar 2. Tumpukan

waste paper/sampah kertas cetakan

\section{Efek sampah produksi dan mutu cetak}

Masalah ketegangan kertas yang tidak optimal kerap terjadi pada proses cetak gulungan dan sangat mempengaruhi hasil cetakan. Selama proses mencetak berlangsung masalah ketegangan kertas ini menggangu proses pencetakan karena mesin akan berhenti. Penghentian mesin menyebabkan pemborosan dan efesiensi serta produktifitas rendah terutama terkait cetak start up karena cetakan awal harus dibuang sebelum cetakan yang berkualitas diperoleh akibat cetak start up yang masih buram (block). Terjadinya cetak start up yang terlalu sering ini pada akhirnya beresiko terhadap kualitas akibat fluktuasi kecepatan karena stop line dan start up. Untuk mengefesiensiserta menimalisir limbah/waste yang didapat dan meningkatkan kualitas hasil cetak yang optimal, frekwensi stop line (pemberentian /istirahat web) harus dikurangi, karena terlalu sering mesin berhenti menyebabkan tidak stabilnya ink water balance dalam proses pencetakan.

\section{Efisiensi waktu produksi}

Dalam proses produksi pasti ada masalah yang terjadi yang menghambat waktu proses produksi berlangsung, begitu juga dengan masalah ketegangan kertas di mesin web gulungan. Komponen yang diatur dengan baik dari persiapan produksi, alur kerja, dan perawatan yang dilakukan secara teratur akan mengurangi pembuangan waktu (down time). Persiapan bahan yang akan digunakan, kemampuan operator dalam mengoperasikan mesin dan merawat kondisi fisik akan berpengaruh besar terhadap efisien waktu saat produksi. Hal ini juga dapat menguntungkan perusahaan karena dapat mempersingkat waktu produksi dan memberikan kepuasan pelayanan terhadap konsumen karena dapat memenuhi pesanan dengan tepat waktu dan benar.

Pada proses cetak berlangsung operator mesin berusaha untuk selalu mengurangi masalah dalam proses cetak. Namun demikian ketegangan kertas adalah sumber masalah yang tidak diharapkan dan diduga sebelumnya pada proses pencetakan. Masalah tersebut pada praktiknya dapat 
mempengaruhi kinerja operator mesin karena

operator sering mendapat tekanan mental dari pimpinan yang menginginkan pekerjaan selesai tepat waktu dan berkurangnya jumlah waste paper / sampahkertas cetakan. Namun akibat masalah ketegangan kertas yang terjadi di mesin Global Web System mengakibatkan kinerja operator jadi menurun dan kepanikan operator cenderung menambah masalah yang terjadi pada proses produksi sehingga berdampak juga pada penambahan waktu yang hilang (down time). Kepanikan operator muncul karena sistem produksi cetak gulungan ini bersifat kontinyu yang melibatkan proses yang panjang. Dalam hal ini, operator perlu dikondisikan untuk tenang dan konsentrasi dalam menyelesaikan masalah pada proses cetak terutama pada cara mengurangi masalah ketegangan kertas.

\section{Permasalahan ketegangan kertas di} mesin web

Masalah ketegangan kertas kerap terjadi pada proses cetak web gulungan mulai dari persiapan sampai akhir pencetakan sering terjadi masalah ketegangan kertas. Permasalahan bisa terjadi disebabkan oleh bahan baku kertas yang digunakan dan setiap komponen atau unit mesin karena mesin cetak web gulunganmerupakan satu kesatuan yang terdiri dari beberapa unit.

\section{Unit Reelstand}

Permasalahaan dalam proses cetak pun pernah terjadi pada unit ini begitu juga masalah ketegangan kertas, inilah beberapa permasalahan yang menyebabkan ketegangan kertas di unit reelstand:

1. Pemasangan double tape.

2. Tegangan kertas gulungan (web tension).

3. Pemasangan as rol pada gulungan kertas.

4. Unit pencetakan

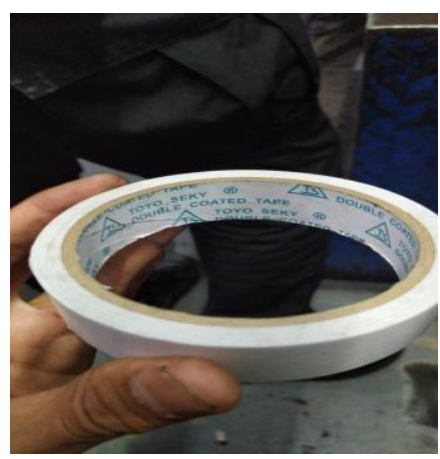

Gambar 3. double tape yang biasa digunakan untuk menyambung gulungan.

Permasalahaan dalam proses pencetakan pernah terjadi pada unit ini begitu juga masalah kertas putus, inilah beberapa permasalahan yang menyebabkan kertas putus di unit pencetakan:

1. Pemberian air pembasah terlalu banyak (banjir).

2. Pemberian tinta yang terlalu berlebihan.

3. Tekanan antara blanket to blanket terlalu tinggi.

4. Sensor Web break tidak membaca kertas.

\section{Unit pengeluaran/folder}

Permasalahaan dalam proses 
juga masalah kertas putus, inilah beberapa permasalahan yang menyebabkan ketegangan kertas di unit folder:

Kertas tergulung pada bagian RTF (Rol To Former).

Kertas putus karena paper jump

Bahan pokok yang di gunakan

Permasalahan dalam proses pencetakan sering terjadi begitu juga yang menyebabkan ketegangan kertas, inilah beberapa permasalahan yang menyebabkan ketegangan kertas yang disebabkan oleh bahan baku kertas yang digunakan:

1. Kerataan dan kecacatan permukaan kertas gulungan.

2. Kecacatan sambungan pabrik kertas.

Faktor - Faktor Penyebab Ketegangan

Kertas.

Masalah ketegangan kertas kerap terjadi pada proses cetak web mulai dari persiapan sampai akhir pencetakan sering terjadi masalah ketegangan kertas di pencetakan web ofset ini. dipengaruhi oleh beberapa faktor yang diantaranya:

1. Kondisi fisik mesin.

2. Kualitas bahan baku yang digunakan.

3. Keterampilan operator cetak.

Faktor kondisi fisik mesin yang kurang optimal bisa menjadi ancaman bagi sebuah perusahaan percetakan karena pengaruh yang diberikan oleh faktor tersebut cukup fital, permasalahan bisa terjadi disetiap komponen atau unit mesin karena mesin cetak web offset merupakan satu kesatuan yang terdiri dari beberapa unit.

\section{Permasalahan yang terjadi pada unit}

\section{Relstand}

Unit Reelstand merupakan unit

paling awal yang terdapat padamesin web

offset, karena unit ini tempat diletakkannya

bahan bakucetak yaitu kertas gulungan.

Permasalahan dalam proses cetakpun pernah terjadi pada unit ini,terutama kertas

putus.Inilah beberapa penyebab ketegangan

kertas pada unit relstand:

1. Pemasangan double tape

Dalam melakukan proses penyambungan kertas gulungan yang habis, kerataan dalam pemasangan double tape merupakan salah faktor yang menjadi penyebab permasalahan pada saat proses pencetakan berlangsung. Pemasangan double tape yang miring dapatmengakibatkan kertas putus tau yang sering disebut gagal sambung, karena posisi sambungan kertas tidak sejajar satu sama lain dan bisa juga mengakibatkan double tipe yang tidak rata pada saat penyambungan menempel dibagian blanket dan mengakibatkan kertas tergulung di blanket. Oleh karenanya seorang operator cetak harus memiliki keterampilan.

2. Tegangan kertas gulungan (web tension)

Bentangan kertas gulungan harus memiliki keteganan yang sesuai pada saat proses pencetakan berlangsung karena 
apabila ketegangan kertas gulungan tidak konstan maka akan timbul permasalahanpermasalahan yang akan menghambat kelangsungan proses cetak. Dampak dari ketidakteraturan tegangan kertas akan langsung mempengaruhi kualitas hasil cetakan seperti ketidaktepatan register cetak, terjadinya doubling, ghosting, dan bahkan dapat mengakibatkan kertas putus.

3. As rol pada gulungan kertas

Dalam pemasangan as rol pada kertas gulungan harus menggunakan as rol yang tidak bocor, karena dalam hasil pengamatan di lapangan saat posisi as rol bocor kertas tidak stabil karna tidak ada yang mengikat pada lodong kertas utuh tersebut dan jalannya kertas tidak teratur yang mempengaruhi ketegangan kertas dan mengakibatkan kertas putus.

\section{Permasalahan yang terjadi pada unit pencetakan}

Unit Pencetakan merupakan unit yang dimana selalu bersinggungan dengan unit pembasah dan unit penintaan yang merupakan salah satu bagianterpenting pada proses pencetakan Permasalahan dalam proses cetakpunpernah terjadi pada unit ini, terutama ketegangan kertas. Berikut beberapa penyebab kertas putus pada unit pencetakan:

1. Pemberian air pembasah terlalu banyak (banjir)

Saat proses pencetakan berlangsung dimana kertas memiliki sifat higrokopis yaitu mudah menyerap air yang disebabkan skala air pembasah terlalu banyak dan kertas pun mengembang, di mana secara bersamaan kertas ditarik dari unit folder dengan cepat dan dapat mengakibatkan kertas putus dan ketegangan kertas tidak maksimal.

2. Pemberian tinta yang terlalu berlebihan Pada proses pencetakan, kertas di transfer tinta melalui blanket yang saling menekan dan pada kejadian ini pemberian tinta terlalu berlebihan memicu terjadi pencabutan serat kertas (picking) yang berlebihan dan mengakibatkan salah satu faktor penyebab ketegangan kertas.

3. Tekanan antara blanket to blanket terlalu berat

Pada proses pencetakan di mesin cetak Global Web System menggunakan system blanket to blanket dan ketika tekanan blanket terlalu berlebihan saat proses pencetakan, terjadi tarik menariknya kertas antara blanket dan tarikan kertas dari folder yang bisa mengakibatkan ketegangan tidak maksimal.

4. Sensor web break tidak membaca kertas Pada saat proses awal cetak yang dimana penyaluran air pembasahmasih belum maksimal yang menyebabkan cetakan masih dalam keadaan kotor (scumming) sensor tidak membaca keadaan kertas yang dimana sensor memberi perintah pisau untuk memotong dan 
web break juga memberi perintah ketika kertas dalam posisi terlalu tegang dan terlalu renggang.

Permasalahan yang terjadi di unit

\section{folder/pengeluaran}

1. Kertas tergulung Pada bagian RTF (Rol To Former)

Pada saat cetakan akan masuk pada unit folder kertas terlalu renggang dan lengket karena pengeringan tinta kurang baik yang menyebabkan kertas tergulung dan mengakibatkan ketegangan kertas tidak maksimal.

\section{Kertas putus karna Paper jamp}

Yang di akibatkan kertas bertumpuk dibagian quartefold dan safety-Pin patah yang mengakibatkan mesin mati secara tiba-tiba dengan ketegangan yang kuat dan mengakibatkan kertas putus akibat kertas terlalu tegang.

\section{Masalah pada Bahan pokok yang}

\section{digunakan pada proses produksi}

1. Kerataan dan kecacatan permukaan kertas gulungan

Bahan baku yang digunakan pada proses pencetakan dengan mesin web offset adalah kertas gulungan atau rol kertas yang berbentuk bulat. Bentuk kertas gulungan yang sudah tidak lagi bulat atau berbentuk oval akanberdampak langsung pada kualitas hasil cetakan, karena ketika kertas gulungan melakukan rotasi akan terjadi perbedaan tegangan kertas dari tiap sisi permukaan kertas gulungan yang mengakibatkan kertas goyang dan terjadi ketidaktepatan register cetakan bahkan terjadi putus/gagal sambung ketika posisi kertas ditarik dengan kecepatan tinggi.

2. Kecacatan sambungan pabrik kertas

Dalam proses cetak kertas yang digunakan harus dengan kualitas yang bagus untuk teroptimalnya hasil cetakan tersebut, namun tidak menyangkut kemungkinan pada proses cetakan berlangsung kertas tiba- tiba putus yang di akibatkan sambungan pabrik kertas saat menggulung kertas menjadi kertas gulungan, hal ini adalah salah satu penyebab putusnya yang disebabkan oleh bahan baku.

Setelah memaparkan penyebab masalah ketegangan kertas gulungan, selanjutnya kami menjelaskan pencegahan dan solusi mengatasi maslah yang dapat terjadi.

Unit Relstand merupakan unit paling awal yang terdapat pada mesin web offset, karena unit ini tempat diletakkannya bahan baku cetak yaitu kertas gulungan. Permasalahan dalam proses cetakpun pernah terjadi pada unit ini terutama kertas putus. Inilah beberapa solusi mengatasi permasalahan kertas putus pada unit relstand:

Pemasangan double tape. Pemasangan double tape yang miring dapat mengakibatkan kertas putus atau yang sering disebut gagal sambung, karena posisi 
sambungan kertastidak sejajar satu sama lain. Oleh karenanya seorang operator cetak harus memiliki keterampilan yang khusus dengan berhati-hati saat penyabungandan melihat kerataan pada saat pemasangan pola double tape agar double tape tidak menempel dan tergulung di blanket serta kerataan gulungan kertas yang akan disambung tidak boleh bergelombang untuk memaksimalkan penyambungan dan proses pencetakan dapat berjalan dengan lancar.

\section{Pengaturan tegangan kertas gulungan (web tension)}

1. Bentangan kertas gulungan harus memiliki ketegangan yang sesuai pada saat proses pencetakan berlangsung dengan mengikuti standar oprasional prosedur dan melihat jalannya kertas memiiki ketegangan yang baik atau tidak dengan mengatur tegangan kertas menggunakan tombol mekanik yang terdapat pada unit Reelstand.

2. Periksa dan pastikan as rol tidak bocor

3. Saat pemasangan as rol pada kertas gulungan pastikan menggunakan as rol yang tidak bocor, agar posisi as roll kertas stabil dan mengikat pada lodong kertas utuh tersebut dan mempengaruhi tegangan kertas menjadi stabil.

Masalah ketegangan kertas juga dapat terjadi dipicu di bagian unit pencetakan yang dapat berupa kertas putus.

Unit Pencetakan merupakan unit yang dimana selalu bersinggungan dengan unit pembasah dan unit penintaan yang merupakan salah satu bagian terpenting pada proses pencetakan. Beberapa solusi penyebab kertas putus pada unit pencetakan:

Pengaturan air pembasah. Kurangi skala air pembasah yang terlalu banyak agar kertas tidak mengembang, dan pada saat kertas ditarik dari unit folder dengan cepat tidak mengakibatkan kertas menjadi mengembang bahkan mengakibatkan kertas putus.

Pengaturan pemberian tinta. Kurangi pemberian tinta yang terlalu berlebihan secara berkala agar tidak memicu terjadi pencabutan serat kertas (picking) yang berlebihan dan mengakibatkan faktor penyebab kertas putus.

Tekanan cetak antara blanket to blanket. Ketika tekanan blanket terlalu berlebihan, kurangi tekanan pada blanket agar pada saat proses pencetakan tidak terjadi tarik menariknya kertas antara blanket dan tarikan kertas dari folder yang bisa mengakibatkan kertas menjadiputus.

Periksa sensor web break. Pada saat proses awal cetak yang dimana penyaluran air pembasah masih belum maksimal yang menyebabkan cetakan masih dalam keadaan kotor (scumming), posisi sensor web break dipastikan dalam keadaan off dan ketika 
cetakan sudah bersih sensor web break disetel pada posisi on. Posisikan kertas tidak terlalu tegang dan terlalu renggang (ketegangan kertas dalam keadaan stabil). Pastikan kebersihan web break terjaga agar dapat digunakan secara optimal. Masalah ketegangan kertas juga terjadi di unit folder/pengeluaran. Pencegahan yang dapat dilakukan adalah sebagai berikut.

Periksa pada bagian RTF (Rol To Former). Pastikan pada saat cetakan akan masuk pada unit folder kertas tidak terlalu renggang. Pastikan tekanan trolly pada unit RTF sesuai dengan jenis dan grammatur kertas yang digunakan. Kurangi pemberian tinta di unit penintaan agar pengeringan tinta jauh lebih baik agar tidak menyebabkan kertas tergulung dan mengakibatkankertas kembali putus. Ketegangan kertas yang terjadi pada bahan kertasnya dapat dihindari dengan melakukanhal-hal berikut.

Pengendalian dan Pemeriksaan kertas gulungan. Dalam proses penurunan kertas dari mobil distribusi kertas (loading paper) ke tempat penyimpanan kertas gulungan harus sesuai dengan SOP yang berlaku di perusahaan agar kertas tidak cacat. Dalam proses penyimpanan kertas gulungan harus memiliki tempat yang sesuai untuk penyimpanan dan memiliki suhu yang baik untuk penyimpanan kertas. Pada saat proses penyimpanan, atur secara berkala waktu penyimpanan kertas jangan sampai kertas tersimpan terlalu lama karena akan mempengaruhi struktur dan sifat pada kertas tersebut. Sebelum kertas masuk ke bagian unit restand periksa fisik kertas gulungan dan permukaan kertas gulungan dalam keadaan baik tidak cacat terlalu parah. Periksa sambungan pada kertas gulungan. Pada proses pencetakan berlangsung pada bagian sisi rol yang memiliki sambungan pabrik ada tanda sambungan dan, ketika kertas telah mendekati sambungan tersebut kecepatan mesin harus diturunkan atau bahkan melakukan sambungan manual. Beri tanda pada saat penyambungan kertas gulungan (web paper), agar pada saat produksi cetakan bisa terkontrol dengan baik dan cetakanyang memiliki sambungantersebut tidak bercampur dengan cetakan yang baik.

\section{KESIMPULAN}

Setelah penulis melakukan pengamatan dan analisis lapangan mengenai ketegangan kertas pada mesin global web system di PT. T, maka penulis dapat menyimpulkan beberapa hal sebagai berikut.

1. Alur Kerja pemasangan kertas gulungan pada unit reelstand harus disediakan standar operasional produksi (SOP) dari mulai pemasangan batang as kedalam kertas gulungan sampai proses webbing pada mesin web gulungan. 
ini banyak hal yang harus diperhatikan seperti spesifikasi double tape, kondisi vakum, tegangan web (web tension), dan masih banyak hal lagi yang apabila diabaikan pada saat proses pemasangan kertas gulungan akan menimbulkan hambatan-hambatan pada saat proses cetak berlangsung dan dapat mempengaruhi kualitas hasil cetakan.

2. Secara garis besar penyebab terjadinya ketegangan kertas pada proses cetak web gulungan mesin Global Web System terhadap proses produksi disebabkan oleh beberapa faktor, yaitu dari faktor kondisi fisik mesin, kondisi bahan baku yang digunakan, dan keterampilan operator cetak.

3. Seringnya terjadi masalah ketegangan kertas pada mesin cetak web berpengaruh terhadap hasil akhir produksi, mulai dari down time yang berlebihan, hasil waste paper yang dihasilkan melebihi target yang ditentukan, kualitas hasil cetakan menurun, dan kurangnya kinerja operator dalam proses pencetakan berlangsung.

4. Dalam proses cetak web ada beberapa cara untuk mengatasi masalah kertas putus yaitu dengan persiapan cetak yang baik yang mengacu kepada SOP, perawatan mesin secara berkala, serta penyimpanan bahan baku yang baik dan benar.

\section{REFERENSI}

Ellger, F., Hilbig, H., Riaz, S., \& Tillmann, P. 2021. Local Newspaper Decline and Political Polarization.

Kulachenko, A., Gradin, P., \& Uesaka, T. 2005. Tension Wrinkling and Fluting in Heatset Web Offset Printing process. Post buckling analyses. Paper presented at the 13th Fundamental Research Symposium on Advances in Paper Science and Technology Location: Univ Cambridge, Cambridge, ENGLAND Date: SEP, 2005.

Manurova, K., \& Horvath, C. 2020. HOW TO BUILD SUSTAINABLE, GREEN PRINTING PLANTS? International Multidisciplinary Scientific GeoConference: SGEM, 20(6.2), 201209.

Svendsen, K., \& Rognes, K. S. 2000. Exposure to organic solvents in the offset printing industry in Norway. Annals of occupational hygiene, 44(2), 119-124.

Trifonova, E. 2020. SIGNIFICANCE OF QUALITY FOR PRINTING COMPETITIVENESS. Paper presented at the Метрология, стандартизация и управление качеством.

Wang, Y. 2020. Printing a road to revolution: 
Vol.7, No. 2, Oktober 2020, hal. 85-99

newspaper and 1911 revolutionary movements in late Qing China. kelebihan-offset-printing, diakses

tanggal 25 Agustus 2020

https://www.infocetak.com/kekurangan-dan- 